\title{
THE COMMUNITY-BASED TOURISM AT THE TOURIST VILLAGE IN THE LOCAL PEOPLE'S PERSPECTIVE
}

\author{
I Made Darma OKA* \\ State Polytechnic of Bali, Tourism Department, Bukit Jimbaran, Bali, 80361, Indonesia, e-mail: madedarmaoka@pnb.ac.id \\ Ni Gst Nym Suci MURNI \\ State Polytechnic of Bali, Tourism Department, Bukit Jimbaran, Bali, 80361, Indonesia, e-mail: gustinymsucimurni@pnb.ac.id
}

\section{Putu Sudhyana MECHA}

State Polytechnic of Banyuwangi, Tourism Department, Banyuwangi, East Java, Indonesia, e-mail: sudhyanamecha@poliwangi.ac.id

\author{
Citation: Oka, I.M.D., Murni, N.G.N.S., \& Mecha, I.P.S. (2021). THE COMMUNITY-BASED TOURISM AT THE TOURIST \\ VILLAGE IN THE LOCAL PEOPLE'S PERSPECTIVE. GeoJournal of Tourism and Geosites, 38(4), $988-996$. \\ https://doi.org/10.30892/gtg.38401-735
}

\begin{abstract}
This study aims to analyze the implementation of community-based tourism (CBT) at the tourist village in the local people's perspective. The data were collected through observation, interview and library research. The key informant was local community who understands implementation of CBT at tourist village, with total 200 respondents. The result shows that the CBT has been well implemented at tourist village. The community perceives that, among the 20 statements mentioned in questionnaire, 2 items show that the local people's perception is very good and 18 is good, meaning that CBT have economically, socially, culturally, environmentally, and politically contributed to them. The test result of the CFA shows that 5 factors have significantly contributed to the implementation of the CBT at tourist village. The result of each variable shows that 19 variables have contributed significantly, only one has not significantly contributed.
\end{abstract}

Key words: implementation, community-based tourism, tourist village, local people, perspective

\section{INTRODUCTION}

The existence of the tourist village in Bali cannot be separated from the high motivation of the local community to contribute to the village development. The higher motivation of the local people, the greater of their participation to the management of the tourist village will be. Their motivation to get involved in the village activities contribute to the success that they will achieve (Meyliani and Rizky, 2018; Putra, 2019). Therefore, their motivation is the main factor contributing to the development of the tourist village. The local people's motivation to manage the tourist village highly contributes to the image of the tourist village, which is then the basic capital for making it a sustainable destination in the future and determines its continuity. Every tourist village attempts to develop the positive image and minimize the negative image (Labato et al., 2006; Putra and Pitana, 2010; Oka and Darmayanti, 2020). The image and sustainability of the tourist village does not only depend on the human resources but also on the extent to which the management can make use of the strengths and opportunities it has and minimize the weaknesses and challenges it faces. In the development of the sustainable tourism, the main thing to which attention should be paid is the local people's participation. It is absolutely needed as the local community is the owner. The community is obliged to control the management and to receive significant proportion generated by the touristic activities (Trejos and Chiang, 2009). However, the local community is less empowered and tends to be the object of the development of the tourist village (Budiasa and Ambarawati, 2014).

The intrinsic obstacle of the CBT is the dependence on the government's top-down political system and limited formal education-related knowledge. The local people expect that they are prioritized in the development of the tourist village to make them more motivated to be responsible for maintaining and perpetuating every potential they have. The local people can be empowered by optimizing three strategies, they are: educating them; accompanying and giving them with the skill of hospitality; and implementing sustainable marketing involving the stakeholders (Junaid, 2021; Astawa et al., 2019). The role played by the related stakeholders is highly needed in the development of the tourist village. Principally, the goal of changing a village into a tourist one is developing it uniqueness which can be developed into a tourist attraction that can empower the local people. Therefore, the elements of the natural and cultural strengths should be optimized in order to develop the tourist village sustainable economically, socially, and environmentally. On the one hand, the development of the rural tourism is intended to develop the natural, social and cultural potentials which can give economic contribution to the local people; on the other hand, the skills that the local people have to develop the tourist village are limited (Sadia and Oka, 2012; Oka et al., 2019; Winia et al., 2019; Darmayanti et al., 2020). This is one of their weaknesses and a challenge which has to be anticipated in the development of the sustainable tourist village. The researchers who have investigated the CBT developed

\footnotetext{
* Corresponding author
} 
in the rural areas from the view of the stakeholders state that the development of tourism has improved the local people's awareness of conserving their culture and environment, and their economy (Kayat, 2008; Hidayah et al., 2019; Utama and Trimurti, 2019). But, not all of the stakeholders play important roles in the development of the rural tourism (Putra, 2019). Those who are academicians and social entrepreneurs play fewer roles in the development of the rural tourism. The strategy of collaborating the stakeholders are needed to effectively empower the local people to make them feel the benefit of the development of the tourist village (Ansell and Gash, 2008; Utomo and Satriawan, 2017). The development of the CBT is an alternative focused on the attempt made to help the economically weak local people (Saayman and Giampiccoli, 2016).

The development of the CBT in the tourist destination can be viewed from 5 factors; they are economic, social, cultural and environmental factors (Suansri and Yeejaw-haw, 2013). The economic motivation and the desire of improving the social status have inspired the local people to get involved in the touristic activities (Sutrisna, 2011). The internal factors (education, family economy) and external factors (social environment, social status) have inspired the local people to get involved in the touristic activities (Winia et al., 2019; Darmayanti and Oka, 2020). The local people's dependence on the government's politics has hampered the implementation of the CBT. However, their strong motivation to change the paradigm they have using the strengths they have to achieve what they want through the management of tourism can anticipate this. Based on what is described above, this article is intended to analyze the implementation of the CBT in the development of the tourist village in the local people's perspective. In addition, this article is also intended to analyze the factors affecting the local people's perception of the implementation of the CBT in the tourist village. This research is important to explore the perception of the local people about the implementation of the CBT. It is expected that the related stakeholders can issue a policy siding with the local people based on what their perception of the implementation of the CBT.

\section{LITERATURE REVIEW}

CBT is closely related to sustainable tourism development. Community participation in tourism planning is more emphasized than tourism products or industry. Several authors have tried to define the term and inevitably create confusion about the true meaning of the term (Saarinen, 2006). Widely accepted definition of sustainable tourism development, stating that it provides guidelines and principles used in all types and forms of tourism including CBT (Ndlovu et al., 2011). This makes CBT an integral component of sustainable development because it requires that the economic, social and cultural benefits for the community are continuously enhanced and their impacts assessed for the benefit of present and future generations. However, the conceptualization of sustainable tourism development has failed to address the problem of rural tourism development (Halstead, 2003). This term has been redefined to suit individual needs which has lost its meaning and is used as a marketing tool to promote market growth rather than incorporating sustainability principles into tourism development. Competitiveness and sustainability are the basis for the successful performance of CBT. Competitiveness is demonstrated by CBT's ability to attract and retain customers through proper marketing and providing quality services and experiences. Sustainability, on the other hand, is the ability of the CBT to ensure that its resources are conserved through demand management, resource management and equitable development. Therefore, CBT must generate individual and collective benefits for community members (Simpson, 2008; Utama and Trimurti, 2019) which must exceed the costs for all involved and offset the resulting tourism impacts (Novelli and Gebhardt, 2007).

The concept of CBT first appeared in (Murphy, 1985) work dealing with the relationship between tourism and its management by local communities in developing countries, a question that was answered again by the same author in 2004 (Murphy and Murphy, 2004). Apart from these two studies, there have been several research investigations analyzing the relationship between tourism and local communities (Richards and Hall, 2000). The CBT concept puts forward new research paths and opportunities for tourism development that integrate with other existing research avenues. It means the local communities need to be involved in tourism planning and management for three basic reasons: enabling people to adapt to change, and ultimately opening up the community mentality because communities are part of the tourism product. The scientific literature documents CBT projects in Asia (Harrison and Schipani, 2007; Manyara and Jones, 2007; Okazaki, 2008; Kibicho, 2008; Trejos and Chiang, 2009). CBT is characterized by the fact that the communities have control over tourism management and receive most of the benefits generated by these activities (Trejos and Chiang, 2009). Thus, this kind of tourism has emerged as a possible solution to overcome the negative impacts of mass tourism in developing countries, thus at the same time becoming a social organization strategy for local communities. The main theme of CBT is integrating food and accommodation services, ancillary services, and tourism management through the community itself. Further basic characteristics should be subsystems that are interconnected with other subsystems (such as education, health, infrastructure and environment), presentation of sustainable development projects managed by communities and linkages between local communities and tourists (Cioce et al., 2007; Oka et al., 2021).

\section{MATERIALS AND METHODS}

The qualitative and quantitative data are used in the current study, which was conducted at four tourist villages in Bali; they are (1) Serangan tourist village, (2) Kaba-kaba tourist village, (3) Tista tourist village, and (4) Bongan tourist village. The data were collected through observation, interview, and library research. The study was conducted from 2019 to 2020 . The informants from whom the data were obtained were those who understand the implementation of the CBT in each tourist village. The key informant was determined using the purposive sampling method. The informants (the community's leaders, management and employees) were deeply interviewed. The data were compared to the local people's perception of the implementation of the CBT. 16 informants (4 from each village) were interviewed. A number of questionnaires were distributed to the local people to obtain the local people's perception of the implementation of the CBT. The questionnaires 
were spread using the stratified random sampling method. The number of samples was determined by referring to what is proposed by Solimun (2002) that the appropriate number of samples to explore at least 5-10 times the number of variables. The study involves 20 variables; however, the samples include 200 respondents (50 from each village) coming from the working age population in order to be more representative. The descriptive quantitative method adopted from the Likert scale was used. The research design is restricted to the qualitative explanation of the implementation of the CBT at the village using the qualitative and quantitative analysis of the assessment made by the local people.

The respondents were requested to fill out the questionnaires, through which their perceptions of the five factors of the CBT was assessed using the score ranging from 1 to 5 which was then analyzed using the Likert scale (Suansri and Yeejawhaw, 2013). Kusmayadi and Sugiarto (2000) state that the Likert scale is an instrument used to measure people's opinion ranging from highly positive to highly negative to show the extent to which they agree or disagree with the statements written in the questionnaire. The results of the measurement were analyzed using the scale 4.20-5.00 (very good), 3.40-4.19 (good), 2.60-3.39 (fair), 1.80-2.59 (poor), 1.00-1.79 (very poor). It is expected that the results of the measurement can reveal the people's perception of the implementation of the CBT at the tourist village comprehensively. Then, the Confirmatory Factor Analysis (CFA) was used to prove whether the local people's perception of the implementation of the CBT was significantly influential or not (Timothy, 2015). The local people's perception of the implementation of the CBT at the tourist village was made in the form of variable $\mathrm{X}_{1}$ to $\mathrm{X}_{20}$ derived from the five factors already determined. The 5 common factors, namely the economic factor $\left(\mathrm{F}_{1}\right)$, the social factor $\left(\mathrm{F}_{2}\right)$, the cultural factor $\left(\mathrm{F}_{3}\right)$, the environmental factor $\left(\mathrm{F}_{4}\right)$, and the political factor $\left(\mathrm{F}_{5}\right)$, which had been already determined led to several results of confirmation test. The factors and variables contributing to the local people's perception of the implementation of the CBT at the tourist village could be identified through this factor analysis.

\section{RESULTS AND DISCUSSION}

Talking about tourism cannot be separated from both the indirect and direct positive and negative impacts on the local people's life. This study is intended to analyze the implementation of the CBT at the tourist village in the local people's perspective. In the analysis of the implementation of the CBT at the tourist village, five factors are classified based on what is proposed. The characteristics of the respondents are discussed as follows (Suansri and Yeejaw-Haw, 2013):

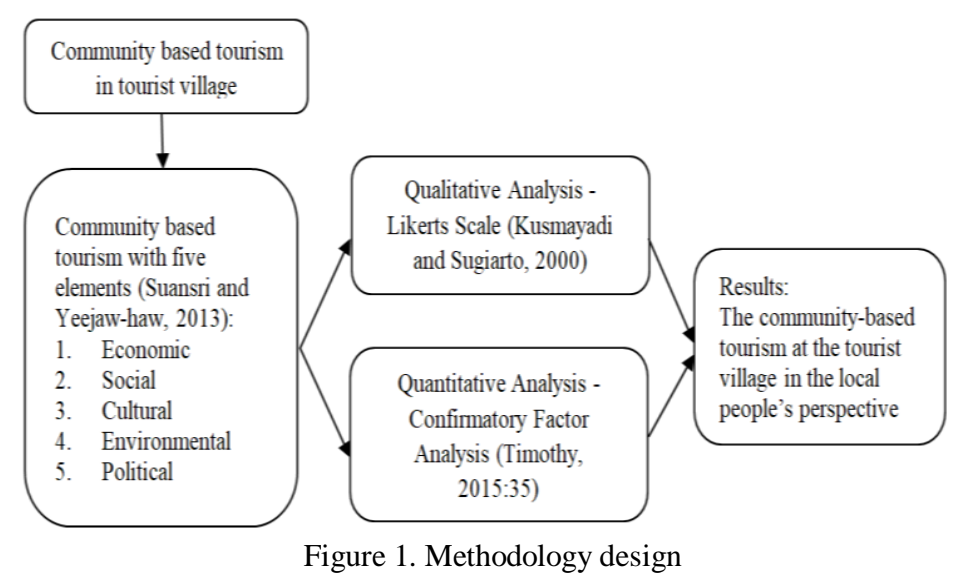

Table 1. The Respondents' Characteristics (Source: Result of the study)

\begin{tabular}{|c|c|c|c|c|}
\hline No & Criteria & & Frequency & Percentage \\
\hline \multirow{5}{*}{1} & \multirow{5}{*}{$\begin{array}{l}\text { Age- } \\
\text { based } \\
\text { Group }\end{array}$} & 18-26 years & 57 & 28.50 \\
\hline & & 27-35 years & 47 & 23.50 \\
\hline & & 36-44 years & 45 & 22.50 \\
\hline & & $45-53$ years & 33 & 16.50 \\
\hline & & $\geq 54$ years & 18 & 9.00 \\
\hline & \multicolumn{2}{|l|}{ Total } & 200 & 100.00 \\
\hline \multirow{3}{*}{2} & \multirow{2}{*}{ Sex } & Male & 117 & 58.50 \\
\hline & & Female & 83 & 41.50 \\
\hline & & Total & 200 & 100.00 \\
\hline \multirow{3}{*}{3} & \multirow{2}{*}{$\begin{array}{c}\text { Marital } \\
\text { Status }\end{array}$} & Married & 131 & 65.50 \\
\hline & & Single & 69 & 34.50 \\
\hline & \multicolumn{2}{|l|}{ Total } & 200 & 100.00 \\
\hline \multirow{6}{*}{4} & \multirow{5}{*}{$\begin{array}{l}\text { Occupa- } \\
\text { tion }\end{array}$} & Civil Servants & 22 & 11.00 \\
\hline & & Private Employees & 42 & 21.00 \\
\hline & & Farmers/Fishermen & 66 & 33.00 \\
\hline & & Laborers & 43 & 21.50 \\
\hline & & Housewives & 27 & 13.50 \\
\hline & \multicolumn{2}{|l|}{ Total } & 200 & 100.00 \\
\hline \multirow{5}{*}{5} & \multirow{5}{*}{ Education } & Elementary School & 0 & 0.00 \\
\hline & & Junior High School & 31 & 15.50 \\
\hline & & Senior High School & 77 & 38.50 \\
\hline & & Diploma $1,2,3$ & 65 & 32.50 \\
\hline & & BA, MA, Ph.D & 27 & 13.50 \\
\hline & \multicolumn{2}{|l|}{ Total } & 200 & 100.00 \\
\hline
\end{tabular}

The results and discussion about this study used the concept of CBT which is mentioned 5 factors that must be applied in the development of tourist villages (Suansri and Yeejaw-haw, 2013). The five factors are: the economic, social, cultural, environmental, and political factors. Furthermore, data analysis is carried out by combine both qualitative analysis (likert scale) and quantitative analysis (CFA) so the local people's perception of CBT implementation in tourist villages are obtained. The steps in data analysis can be presented, as follows:

\section{The Respondents' Characteristics}

The existence of the respondents' characteristics is viewed from 5 criteria; they are: age, sex, marital status, occupation, and education (Table 1). Based on the age-based group, those who assessed the implementation of the CBT at the tourist village dominantly ranged from 18 to 26 years of age (28.50\%), followed by those ranging from 27 to 35 years of age (23.50\%) and those ranging from 46-44 years of age (22.50\%). This indicates that the young people at the tourist village seriously pay attention to the development of tourism at their villages. They are aware that they are the next generation of the tourism developed at their respective village. Viewed from the sex-based group, 58.50\% are male and $41.50 \%$ are female. Viewed from the marital status-based group $65.50 \%$ are married and $34.50 \%$ are single. Seen from the occupationbased group, $33.00 \%$ are farmers/fishermen, $21.00 \%$ are private employees, $21.50 \%$ are laborers, $13.50 \%$ are housewives, and $11.00 \%$ are government civil servants. Based on the level of their education, $38.50 \%$ are senior high school graduates, $32.50 \%$ are diploma graduates, $13.50 \%$ have completed undergraduate program, and $15.50 \%$ are junior high school graduates. 


\section{Validity Test and Reliability Test}

It is expected that the results of the validity and reliability tests can be statistically used to measure the validity and reliability of the variables. In the initial stage the questionnaires were distributed to 30 respondents and the external validity test the samples tested total more or less 30 (Sugiyono, 2014). The result of the validity test conducted in the current study shows that the 20 questions of every variable indicator used in the questionnaire can be stated to be valid as the value of count $r$ is $>0.30$. Apart from that, it is stated that if the correlation of every indicator is positive and is over 0.30 , then such a factor will become a strong construct or an instrument with a good construction validity. In this current study the validity test was conducted using SPSS 17 for windows for every item of statement in the questionnaire classified into five factors; they are the economic, social, cultural, environmental and political factors.

The reliability test shows the extent to which a measurement can lead to the result which is not different from that obtained from the re-measurement of the same subject. The reliability test is used once when the data is taken and is used to analyze the questionnaire. The scale ranging from 0 to 1 is used with the alpha cronbach formula in which it is stated that an instrument will be reliable if the value of alpha cronbach is $>0.6$ which is significant (Simamora, 2001).

The test was conducted for the 5 factors, namely the economic, social, cultural, environmental and political factors. The economic factor consists of 4 items of statements; namely, the development of tourism in the rural area economically benefits the local people $\left(\mathrm{x}_{1}\right)$, the development of tourism at the tourist village can improve the local people's income $\left(\mathrm{x}_{2}\right)$, the development of tourism can create new job opportunities for the local people $\left(\mathrm{x}_{3}\right)$, the development of tourism can give contribution in the form of funds to the local people $\left(\mathrm{x}_{4}\right)$. The social factor includes: the development of the tourist village can improve the local people's social status $\left(\mathrm{x}_{5}\right)$, the local people are proud of developing the tourist village $\left(\mathrm{x}_{6}\right)$, the local people play an active role in supporting the touristic activities at their village $\left(\mathrm{x}_{7}\right)$, the local people work together to organize the touristic activities at their village $\left(\mathrm{x}_{8}\right)$. The cultural factor includes: the touristic activities at the village involve the nature and culture $\left(\mathrm{x}_{9}\right)$, the touristic activities are in accordance with the local culture $\left(\mathrm{x}_{10}\right)$, the impact of the western culture can enrich the local culture $\left(\mathrm{x}_{11}\right)$, the development of tourism at the village causes the local people to be affected by the western culture $\left(\mathrm{x}_{12}\right)$. The environmental factor includes: the local people are actively involved in the conservation of the rural nature $\left(\mathrm{x}_{13}\right)$, the local people actively maintain the environmental cleanliness $\left(\mathrm{x}_{14}\right)$, the conservation of the nature is a positive step taken to conserve the environmental ecosystem $\left(\mathrm{x}_{15}\right)$, and the existence of the tourist village can apply the principle of the environmental sustainability $\left(\mathrm{x}_{16}\right)$. The political factor includes: the development of the tourist village can increase the local people's participation $\left(\mathrm{x}_{17}\right)$, increasing the power of the local people as the management of the touristic activities $\left(\mathrm{x}_{18}\right)$, the development of the tourist village still guarantees the local people's rights to manage the natural resources $\left(\mathrm{x}_{19}\right)$, the local people are actively involved in the rural touristic activities starting from the phase in which they are planned, the phase in which they are carried out, the phase in which they are controlled, to the phase in which they are evaluated (x20).

Each factor represented by 4 items of statements above leads to the degree of significance, that is, 0.908 , meaning that the questionnaire is reliable enough to be used as a research instrument. Based on the results of the validity and reliability tests, it can be concluded that the research instrument used is valid and it can produce a good moment product and is reliable as its value is relatively consistent, namely $>0.60$. Having fulfilled the results of validity and reliability, the current study keeps using questionnaire as an instrument. The answers given by the respondents to the statements in the questionnaire depend on their own perceptions. The result of all the data on frequency and the result of the analysis of all items are narratively and verbally described as the interpretation of each dimension as follows:

Table 2. The Local People's Perception of the Implementation of CBT at the Tourist Village (Source: Data Processed, 2020)

\begin{tabular}{|c|c|c|c|c|c|c|c|c|c|}
\hline \multirow[b]{2}{*}{ Factor } & \multirow{2}{*}{ Variable } & \multicolumn{5}{|c|}{ Option } & \multirow[b]{2}{*}{$\Sigma$} & \multirow{2}{*}{ Average } & \multirow{2}{*}{ Criteria } \\
\hline & & 5 & 4 & 3 & 2 & 1 & & & \\
\hline \multirow{4}{*}{ Economic } & Economic advantage $\left(\mathrm{x}_{1}\right)$ & 485 & 244 & 93 & 14 & 4 & 840 & 4.20 & Very Good \\
\hline & Increasing income $\left(\mathrm{x}_{2}\right)$ & 230 & 416 & 141 & 2 & 2 & 791 & 3.96 & Good \\
\hline & Opening new job opportunities $\left(\mathrm{x}_{3}\right)$ & 295 & 360 & 129 & 2 & 7 & 793 & 3.97 & Good \\
\hline & Giving contribution in the form funds $\left(\mathrm{x}_{4}\right)$ & 360 & 312 & 117 & 6 & 8 & 803 & 4.02 & Good \\
\hline \multirow{4}{*}{ Social } & Improving social status $\left(\mathrm{x}_{5}\right)$ & 315 & 344 & 114 & 12 & 7 & 792 & 3.96 & Good \\
\hline & Increasing pride $\left(\mathrm{x}_{6}\right)$ & 280 & 340 & 111 & 28 & 8 & 767 & 3.84 & Good \\
\hline & Increasing role $\left(\mathrm{x}_{7}\right)$ & 330 & 304 & 123 & 28 & 3 & 788 & 3.94 & Good \\
\hline & Improving cooperation $\left(\mathrm{x}_{8}\right)$ & 300 & 328 & 156 & 8 & 2 & 794 & 3.97 & Good \\
\hline \multirow{4}{*}{ Cultural } & Involving the nature, culture, tourism with s & 405 & 308 & 120 & 2 & 8 & 843 & 4.22 & Very Good \\
\hline & Being relevant to the local culture $\left(\mathrm{x}_{10}\right)$ & 350 & 324 & 117 & 4 & 8 & 803 & 4.02 & Good \\
\hline & Strengthening the local culure $\left(\mathrm{x}_{11}\right)$ & 315 & 368 & 99 & 8 & 8 & 798 & 3.99 & Good \\
\hline & Getting affected by the western culture & 180 & 276 & 189 & 64 & 0 & 709 & 3.55 & Good \\
\hline \multirow{4}{*}{ Environment } & Conserving the nature $\left(\mathrm{x}_{13}\right)$ & 270 & 276 & 162 & 34 & 6 & 748 & 3.74 & Good \\
\hline & Keeping the natural environment clean $\left(\mathrm{x}_{14}\right)$ & 195 & 384 & 138 & 38 & 0 & 755 & 3.78 & Good \\
\hline & Conserving the environmental ecosystem $\left(\mathrm{x}_{15}\right)$ & 305 & 344 & 120 & 26 & 0 & 795 & 3.98 & Good \\
\hline & Keeping the environment sustainable $\left(\mathrm{x}_{16}\right)$ & 315 & 280 & 159 & 28 & 0 & 782 & 3.91 & Good \\
\hline \multirow{4}{*}{ Politic } & Improving the local people's participation $\left(\mathrm{x}_{17}\right)$ & 175 & 256 & 192 & 68 & 3 & 694 & 3.47 & Good \\
\hline & Strengthening the local people's power $\left(\mathrm{x}_{18}\right)$ & 250 & 276 & 180 & 34 & 4 & 744 & 3.72 & Good \\
\hline & Guaranteeing the local people's rights $\left(\mathrm{x}_{19}\right)$ & 370 & 320 & 99 & 18 & 4 & 811 & 4.06 & Good \\
\hline & Motivating the local people to be active in the touristic activities $\left(\mathrm{x}_{20}\right)$ & 165 & 320 & 165 & 50 & 7 & 707 & 3.54 & Good \\
\hline
\end{tabular}

In the initial step, the scores are converted as follows: highly agree $=5$, agree $=4$, hesitate $=3$, less agree $=2$, and disagree $=1$. The rating of the evaluation made by the local people of the implementation of the CBT at the tourist village is shown in Table 2. 


\section{Rating of the Local People's Perception}

The local people's perception of the implementation of the CBT at the tourist village classified into 5 factors; they are: the economic, social, cultural, environmental, and political factors (Suansri and Yeejaw-haw, 2013). The Likert scale is used to measure the perception.

\section{Analysis of the Factors}

The result of the test of the local people's perception of the implementation of the CBT at the tourist village can be seen in Table 3, the five factors (the economic, social, cultural, environmental and political factors) used to measure the local people's perception of the implementation of the CBT at the tourist village are presented in the form of research variables, totaling 20 indicators. They are all measurable indicators and are used to measure the local people's perception of the implementation of the CBT at the tourist village. Several tests were conducted to see whether there is a correlation or not. Two of them are (a) the Kaiser Meyer Olkin Test (KMO), which is conducted to identify the appropriateness of the samples. The factor analysis is regarded as appropriate if KMO is $>0.05$; and (b) Barlett's test of Spericity, which is used to identify that the variables in the samples vary.

Table 3. KMO dan Barlett's test of the Local People's Perception of the Implementation of CBT at the Tourist Village (Sources: SPSS Data Processed, 2020)

\begin{tabular}{|c|c|c|c|c|c|c|c|}
\hline \multirow{2}{*}{ No } & \multirow{2}{*}{ Types of Measurement } & \multicolumn{5}{|c|}{ Factors } \\
\cline { 3 - 8 } & $\begin{array}{c}\text { Eco- } \\
\text { nomic }\end{array}$ & Social & Cultural & $\begin{array}{c}\text { Environ- } \\
\text { ment }\end{array}$ & Politic \\
\hline 1 & $\begin{array}{c}\text { Kaiser-Meyer Olkin } \\
\text { Measure of Sampling Adequacy }\end{array}$ & .772 & .747 & .619 & .646 & .643 \\
\hline \multirow{2}{*}{2} & \multirow{2}{*}{$\begin{array}{c}\text { Bartlett's Test } \\
\text { of Sphericity }\end{array}$} & $\begin{array}{c}\text { Approx. Chi- } \\
\text { Square }\end{array}$ & 255.472 & 199.689 & 123.416 & 199.370 & 236.258 \\
\cline { 2 - 8 } & Df & 6 & 6 & 6 & 6 & 6 \\
\cline { 2 - 8 } & Sig. & .000 & 000 & .000 & .000 & .000 \\
\hline
\end{tabular}

Tabel 4. Total Variance Explaining the Local People's Perception of the CBT at the Tourist Village (Sources: SPSS Data Processed, 2020)

\begin{tabular}{|c|c|c|c|c|}
\hline \multirow{2}{*}{ No } & \multirow{2}{*}{ Factor } & \multicolumn{3}{|c|}{ Intial Egienvalues } \\
\cline { 3 - 5 } & & Total & $\begin{array}{c}\% \text { of } \\
\text { Variance }\end{array}$ & $\begin{array}{c}\text { Cumulative } \\
\%\end{array}$ \\
\hline 1 & Economic & 2.547 & 63.684 & 63.684 \\
\hline 2 & Social & 2.340 & 58.502 & 58.502 \\
\hline 3 & Cultural & 1.959 & 48.976 & 48.976 \\
\hline 4 & Environmental & 2.213 & 55.317 & 55.317 \\
\hline 5 & Political & 2.273 & 56.813 & 56.813 \\
\hline
\end{tabular}

From the correlational matrix, the interrelation among the factors (the economic, social, cultural, environmental, and political factors) and among the variables can be identified through the appropriateness test model using the KMO test and Barlett test. Simultaneously, the appropriateness of the model used to obtain the result of 0.851 using the Bartlett test leads to the value of significance, namely 0,000 . Then, the appropriateness of the model used for each factor is partially tested. The economic factor forming variable tested using the KMO test leads to the result 0.772 , and that tested using the Barlett test leads to the value of significance, namely 0.000 . The result of the cultural forming variable using the KMO test is 0.619 with 0,000 as the value of significance. The result of the environmental factor forming variable tested using the KMO test is 0.646 with 0.000 as the value of significance.

Table 5. The Analysis Factor of the Local People's Perception of the Implementation of CBT (Source: SPSS Data Processed, 2020)

\begin{tabular}{|c|c|c|c|c|}
\hline Factor & Variable & \begin{tabular}{|l|} 
Coefisien Corelation \\
\end{tabular} & Determined & Remark \\
\hline \multirow{4}{*}{ Economic } & Economic advantage $\left(\mathrm{x}_{1}\right)$ & 0.806 & $>0.60$ & Significant \\
\hline & Increasing income $\left(\mathrm{x}_{2}\right)$ & 0.806 & $>0.60$ & Significant \\
\hline & Opening new job opportunities $\left(\mathrm{x}_{3}\right)$ & 0.800 & $>0.60$ & Significant \\
\hline & Giving contribution in the form funds $\left(\mathrm{x}_{4}\right)$ & 0.779 & $>0.60$ & Significant \\
\hline \multirow{4}{*}{ Social } & Improving social status $\left(\mathrm{x}_{5}\right)$ & 0.835 & $>0.60$ & Significant \\
\hline & Increasing pride $\left(\mathrm{x}_{6}\right)$ & 0.798 & $>0.60$ & Significant \\
\hline & Increasing role $\left(\mathrm{x}_{7}\right)$ & 0.754 & $>0.60$ & Significant \\
\hline & Improving cooperation $\left(\mathrm{x}_{8}\right)$ & 0.661 & $>0.60$ & Significant \\
\hline \multirow{4}{*}{ Cultural } & Involving the nature, culture, tourism with special interest $\left(\mathrm{x}_{9}\right)$ & 0.844 & $>0.60$ & Significant \\
\hline & Being relevant to the local culture $\left(\mathrm{x}_{10}\right)$ & 0.669 & $>0.60$ & Significant \\
\hline & Strengthening the local culure $\left(\mathrm{x}_{11}\right)$ & 0.661 & $>0.60$ & Significant \\
\hline & Getting affected by the western culture (x12) & 0.603 & $>0.60$ & Significant \\
\hline \multirow{4}{*}{ Environment } & Conserving the nature $\left(\mathrm{x}_{13}\right)$ & 0.865 & $>0.60$ & Significant \\
\hline & Keeping the natural environment clean $\left(\mathrm{x}_{14}\right)$ & 0.782 & $>0.60$ & Significant \\
\hline & Conserving the environmental ecosystem $\left(\mathrm{x}_{15}\right)$ & 0.773 & $>0.60$ & Significant \\
\hline & Keeping the environment sustainable $\left(\mathrm{x}_{16}\right)$ & 0.506 & $>0.60$ & Not Significant \\
\hline \multirow{4}{*}{ Politic } & Improving the local people's participation $\left(\mathrm{x}_{17}\right)$ & 0.869 & $>0.60$ & Significant \\
\hline & Strengthening the local people's power $\left(\mathrm{x}_{18}\right)$ & 0.835 & $>0.60$ & Significant \\
\hline & Guaranteeing the local people's rights $\left(\mathrm{x}_{19}\right)$ & 0.659 & $>0.60$ & Significant \\
\hline & Motivating the local people to be active in the touristic activities $\left(\mathrm{x}_{20}\right)$ & 0.621 & $>0.60$ & Significant \\
\hline
\end{tabular}

Then, the result of the political forming variable tested using the KMO test is 0.643 with 0.000 as the value of significance. The value of each factor forming variable shows that the result is $>0.05$, meaning that the model of analysis used for each factor forming variable is appropriate and that each contributes to the local people's perception of the 
implementation of the CBT at the tourist village. After that, the results of the tests are interpreted based on the values appearing from the results of analyses after the factors explored are regarded as reasonable enough to go to the model of appropriateness test. The other types of information obtained from the qualitative data source such as the information given by the informants interviewed are also included in the interpretation.

The results of all the statistical analyses and the data on frequency from all the variables are narratively and verbally described in what is interpreted from each shown in Table 5.

\section{a. The Economic Factor}

From the result of the analysis of the four variables $\left(\mathrm{x}_{1, \ldots \mathrm{X} 4}\right)$ of the economic factor, it can be seen that each variable significantly contributes to the local people's perception of the implementation of the CBT at the tourist village. Cumulatively, the contribution of all the variables in the economic factor is 63.684 (Table 4). This shows that the eigen value of each variable indicated by the contribution of the value of each component of the economic factor cumulatively and significantly affect the local people's perception of the implementation of the CBT at the tourist village.

Then, the correlational coefficient value of each variable indicator of the economic factor is $>0.60$ (Table 5), meaning that the contribution of all of the indicators of the variables of the economic factor to the local people's perception of the implementation of the CBT at the tourist village is real.

This is supported by the tabulation analysis of the local people's opinions (Table 2) that the degree of the local people's perception of the indicator variable that the development of tourism at the tourist village economically benefit them is 4.20 (very good); the contribution in the form of funds to the local people generated from the development of tourism is 4.02 (good); and the new job opportunities created from the development of rural tourism for the local people is 3.97 (good). This means that the local people perceive and feel that the implementation of the CBT at the tourist village is useful to their life, as justified by the local community's leaders. According to them, the implementation of the CBT at the tourist village economically benefits the local people and increases the sales of the local products. This condition proves that the implementation of the CBT at the tourist village greatly contributes to the local people's life as it can improve their economy. This result of the study supports the results of the previous studies which it is stated that the development of the tourist village can improve and increase the local people's economy and welfare (Ishii, 2012; Agarwal, 2012; Cole, 2012; Suasapha and Paturusi, 2015; Priatmoko et al., 2021)

\section{b. The Social Factor}

The result of the test of the social factor is 0.747 , higher than the value determined by the model of analysis used, namely 0.05 , meaning that statistically the social factor has the model appropriate to the degree of significance, that is, 0.000. Then, the result of the factor analysis of variables $\mathrm{x}_{5} \ldots \mathrm{x}_{8}$ shows one component of the social factor $\left(\mathrm{F}_{2}\right)$ with the eigen value that can explain diversity, that is, 58.502\% (Table 4). This means that the eigen value of each variable indicated by the contribution of the value of each component cumulatively significantly contributes to the local people's perception of the implementation of the CBT at the tourist village. The correlational coefficient value of each variable indicator of the social factor is $>0.60$ (Table 5), meaning that the contribution of all the variable indicators of the social factor is real. This is supported by what is stated by the local people (Table 2) that the degree of the local people's perception of the variable indicator that the development of the tourist village can increase the social status is 3.96 (good); the local people's pride of the development of the rural tourism is 3.84 (good); the local people's ability to play an active role in the development of the rural tourism is 3.94 (good); and the local people's mutual cooperation in organizing the touristic activities at the village is 3.97 (good). However, in the studies conducted by Scott (2012) and Mahfud et al., (2015) it is stated that the development of new tourist areas need to determine that the social benefit is higher than the economic benefit to make them sustainable for the next generation.

\section{c. The Cultural Factor}

The value of the cultural factor is $>0.05$, that is, 0.619 . This shows that statistically the model of the component of the cultural factor is appropriate to the factor analysis with the value of significance 0,000. From the result of the factor analysis of the four variables $\left(\mathrm{x}_{9}, \ldots \mathrm{x}_{12}\right)$, it is found that the eigen value of one factor component determining the variables included in the cultural factor that can explain total diversity is $48.976 \%$ (Table 4). Based on the contribution of the variables of the cultural factor, it can be stated that they all significantly contribute to the local people's perception of the implementation of the CBT at the tourist village, meaning that it is very important to pay attention to the cultural factor to make the tourist village sustainable. Further, it is found that the correlational value of each variable indicator in the cultural factor is $>0.60$ (Table 5), meaning that the contribution of all the variable indicators of the cultural factor is real. This is supported by the tabulation of local people's opinions (Table 2) that the value of their perception of the variable indicator of the touristic activities at the rural area involving the nature and culture is 4.02 (good); that the value of the touristic activities at the tourist village which do not contradict the local culture is 3.00 (good), and that the value of the development of rural tourism causing the local people to be affected by the western culture is 3.55 (good).

The informants, Made Sedana who is from Serangan village, Made Rata who is from Kaba-Kaba village, Wayan Nadi who is from Bongan village, and Made Citra Dewi who is from Tista village state that they feel that the implementation of the CBT at the tourist village can make the local people more aware that the cultural tradition they have should be conserved and can also anticipate the negative impact of the western culture. They understand that the aim of the tourists to visit the tourist village is to watch the diversification of the local people's culture. This supports 
the results of the previous studies which is stated that serious attention should be paid to the cultural elements in the development of tourism as culture is one of the distinctive features which needs conserving in the development of sustainable tourism (Gelbman and Timothy, 2011; Oka et al., 2017).

\section{d. The Environmental Factor}

The value of the environmental factor is $>0.05$, that is, 0.649 . This shows that statistically the model of the component of the environmental factor appropriate to the factor analysis with the value of significance 0.000 . The result of the factor analysis of the four variables $\left(\mathrm{x}_{13 \ldots} \mathrm{x}_{16}\right)$ shows that the eigen value of one of the factor components determining the variables in the environmental factor that can explain the total diversity is 55.317\% (Table 4). Based on the extent to which the variables of the environment contribute to the local people's perception of the implementation of the CBT at the tourist village, it can be stated that, as a whole, they significantly contribute, meaning that the environmental factor plays an important role in the development of the tourist village.

Then, the correlational coefficient value of each variable indicator of the environmental factor shows that the value of one variable is $<0.60$ (Table 5), namely the variable of the existence of the tourist village can implement the principle of the environmental sustainability, meaning that this is the only this variable which does not contribute significantly and that the other variables do. The result of the tabulation analysis of what is stated by the local people (Table 2) shows that the extent to which they perceive the environmental factor is positive. This is supported by the value of the opinion that the local people are actively involved in conserving the rural nature is 3.74 (good); the value of the extent to which they actively keep the natural environment clean is 3.78 (good); the value of the natural conservation as a positive step taken to conserve the environmental ecosystem is 3.98 (good), meaning that the natural conservation is regarded as highly significant to attract tourists to come, inspired by the distinctive feature of the rural nature for the tourists who love environment. The development of tourist destinations requires the real balanced development of economic benefit and natural environment and the maximum empowerment of the local people (Alavalapati et al., 2000). Serious attention needs to be paid to the elements of the cultural, social and physical environments in the development of sustainable tourism for the next generation to enjoy (Gelbman and Timothy, 2011)

\section{e. The Political Factor}

The value of the political factor obtained is $>0.05$, that is, 0.643 . This shows that statistically the model of analysis of the component of the political factor is appropriate to the factor analysis with the value of significance 0.000 . The eigen value of the result of the factor analysis of the four variables investigated $\left(\mathrm{x}_{17, \ldots} \mathrm{x}_{20}\right)$ that can explain total diversity is $56.813 \%$ (Table 4). Based on the extent to which the variables of the political factors contribute to the local perception to the implementation of the CBT at the tourist village, it can be stated that they, as a whole, significantly contribute, meaning that the political factor also plays an important role in the sustainable development of the tourist village. Then, the correlational coefficient value of each variable indicator of political factors is found to be $>0.60$ (Table 5), meaning that the contribution of the variable indicators of political factor to the local people's perception of the implementation of the CBT at the tourist village is real. The result of the tabulation analysis (Table 2) shows that the extent to which the local people's perception of the political factor is positive enough.

This is supported by the value of the opinion of the local people that the development of rural tourism can improve their participation is 3.47 (good), the value of the development of rural tourism that can increase the power of the local people as the management of the touristic activities at the village is 3.72 (good), the value of the development of rural tourism that keeps guaranteeing the local people's rights in the management of the natural resources the village has is 4.06 (good), and the value of the local people actively involved in the touristic activities at the village starting from when they are planned, implemented, supervised to when they are evaluated is 3.54 (good).

That is justified by the informants (Wayan Karma, who is from Serangan village; Ni Made Sulatri, who is from Kaba-Kaba village; Wayan Wirya, who is from Bongan village; and Nyoman Sangka, who is from Tista village). They state that the development of rural tourism prioritizes, for example, the recruitment of the local people in its management, meaning that they have felt the benefit of the implementation of CBT. The reason is that they are maximally empowered by the management of the tourist village. This supports the results of the previous studies which state that the local people are the important agents of the development of the tourist village starting from when it is planned, when it is implemented to when it is evaluated (Reid et al., 2004; Trejos and Chiang, 2009; Dewi et al., 2013). The attention should be paid to the attitude of the local government and the local people's view when developing sustainable tourism (Nunkoo et al., 2012). CBT-related activities in Indonesia are not only dependent on the community's solidarity as stated in the results of the studies previously conducted but also on the community's formal and informal leaders (Setiawina et al., 2020).

\section{CONCLUSIONS}

Based on what is described above, it can be concluded that the CBT at the tourist villages has been well implemented. The local people's perceptions of the 20 items of statements in the questionnaire are very good and good, meaning that it is recognized that the implementation of the CBT at the tourist villages has positively contributed to the local people's life. The statistical tests show that the 5 factors, namely the economic, social, cultural, environmental and political factors have significantly contributed to the implementation of the CBT at the tourist villages. Apart from that, the result of the test of each variable shows that almost all of the variables tested in the current study have significantly 
contributed, except the variable of the existence of the tourist village that can apply the principle of the environmental sustainability. This indicates that the benefit of the implementation of the CBT at the tourist village has been really felt by the local people. This condition proves that the village developed into a tourist one has been able to benefit the local people economically, socially, culturally, environmentally and politically.

\section{Acknowledgement}

The Indonesian government through the Directorate General of Research and Development of the Ministry of Research, Technology and Higher Education has funded this research so that it can be completed on time. The informants in each tourist village who have been willing to provide information in data collection.

\section{REFERENCES}

Agarwal, S. (2012). Resort economy and direct economic linkages. Annals of Tourism Research, 39(4), 1470-1494. https://doi:10.1016/j.annals.2012.04.001

Alavalapati, J.R.R., \& Adamwicz, W. (2000). Tourism impact modelling for resource extaction regions. Annals of Tourism Research, 27(1), 188-202. https://doi:10.1016/s0160-7383(99)00064-x

Ansell, C., \& Gash, A. (2008). Collaborative governance in theory and practice. Journal of Public Administration Research and Theory, 18(4), 543-571. https://doi:10.1093/jopart/mum032

Astawa, I P., Sukawati, T.G.R., \& Sugiartha, I N.G. (2019). Developing a harmonius culture-based sustainable event model in Bali Tourism Village. Geojurnal of Tourism and Geosites, 25(2), 446-462. https://doi:10.30892/gtg.25214-372

Budiasa, I W., \& Ambarawati, I G.A.A. (2014). Community-based agro-tourism as an innovative integrated farming system development model towards sustainable agriculture and tourism in Bali. Journal ISSAAS, 20(1), 29-40.

Cioce, C.A., Bona, M., \& Ribeiro, F.H. (2007). Community tourism: montanha beija-flor dourado pilot project (microbasin of the Sagrado River, Morretes, Paraná). Turismo-Visao e Açao, 9(2), 249-266.

Cole, S. (2012). A political ecology of water equity and tourism: a case study from Bali. Annals of Tourism Research, 39(2), $1221-1241$. https://doi:10.1016/j.annals.2012.01.003

Darmayanti, P.W., \& Oka, I M.D. (2020). Implikasi Pengembangan Pariwisata Berbasis Masyarakat Bagi Masyarakat Di Desa Bongan [Implications of community-based tourism development for the community in Bongan Village]. Jurnal Ilmiah Hospitality Management, 10(2), 33-41. https://doi.org/10.22334/jihm.v10i2.167

Darmayanti, P.W., Oka, I M.D., \& Sukita, I.W. (2020). Pengembangan Desa Wisata Kaba-Kaba dalam perspektif masyarakat lokal. [Development of Kaba-Kaba Tourism Village in the perspective of the local community]. Jurnal Ilmiah Hospitality Management, 11(01), 15-23. https://doi.org/doi: 10.22334/jihm.v11i1.173

Dewi, M.H.U., Chafid, F., \& Baiquni, M. (2013). Pengembangan Desa Wisata Berbasis Partisipasi Masyarakat Lokal Di Desa Wisata Jatiluwih Tabanan, Bali. [Development of a tourism village based on local community participation in Jatiluwih Tourism Village, Tabanan]. Kawistara. Jurnal Ilmiah Sosial Humaniora, 3(2), 117-126. https://doi.org/10.22146/kawistara.3976

Gelbman, A., \& Timothy, D. (2011). Border complexity, tourism and international exclaves A case studyTitle. Annals of Tourism Research, 38(1), 110-131. https://doi.org/10.1016/j.annals.2010.06.002

Halstead, L. (2003). Making CBT work: An Assessment of Factors Contributing to Successful Community-Owned Tourism Development in Caprivi, Namibia, Windhoek. United Kingdom. http://www.dea.met.gov.na

Harrison, D., \& Schipani, S. (2007). Lao tourism and proverty alleviation: CBT and the private sector. Current Issues in Tourism, 10(2), 194-230. https://doi.org/10.2167/cit310.0

Hidayah, N.A., Hutagalung, S.S., \& Hermawan, D. (2019). Analisis Peran Stakeholder Dalam Pengembangan Wisata Talang Air Peninggalan Kolonial Belanda di Kelurahan Pajaresuk Kabupaten Pringsewu [Analysis of the Role of Stakeholders in the Development of the Dutch Colonial Heritage Gutter Tourism in Pajaresuk Vil. Jurnal Ilmu Administrasi Publik, 7(1), 55-71. http://dx.doi.org/10.31289/publika.v7i1.2179

Ishii, K. (2012). The Impact of ethnic tourism on hill tribes in Thailand. Annals of Tourism Research, 39(1), 290-310. http://doi:10.1016/j.annals.2011.05.004

Junaid, I. (2021). Community empowerments strategy for economic opportunities in Selayar Islands Regency, South Sulawesi. Masyarakat, Kebudayaan Dan Politik, 34(1), 72-80. https://doi.org/10.20473/mkp.v34i12021.72-80

Kayat, K. (2008). Stakeholders perspectives toward a community-based rural tourism development. European Journal of Tourism Research, 1(2), 94-112.

Kibicho, W. (2008). CBT: A factor-cluster segmentation approach. Journal of Sustainable Tourism, 16(2), $211-231$. https://doi.org/doi:10.2167/jost623.0

Kusmayadi, \& Sugiarto, E. (2000). Metodologi Penelitian dalam Bidang Kepariwisataan [Research Methodology in the Field of Tourism]. PT. Gramedia Pustaka Utama, Indonesia

Labato, L.H., Radilla, M.M.T., \& Garcia, J.S. (2006). Tourism Destination Image, Satisfation and Loyalty; A case study in IxtapaZihuatanejo. Mexico. Tourism Geographiec, 8(4), 343-358. https://doi.org/10.1080/14616680600922039

Mahfud, M.A.Z., Haryono, B.S., \& Anggraeni, N.L.V. (2015). Peran Dan Koordinasi Stakeholder Dalam Pengembangan Kawasan Minapolitan Di Kecamatan Nglegok, Kabupaten Blitar [The Role and Coordination of Stakeholders in the Development of the Minapolitan Area in Nglegok District, Blitar Regency). Jurnal Administrasi Publik, 3(12), 2070-2076.

Manyara, G., \& Jones, E. (2007). CBT enterprises development in Kenya: An exploration of their potential as avenues of poverty reduction. Journal of Sustainable Tourism, 15(6), 628-644. https://doi.org/10.2167/jost723.0

Meyliani, L., \& Rizky, M.N. (2018). Keinginan untuk maju: Strategi Desa Ranuklindungan dalam Mewujudkan Desa Wisata. Kepariwisataan Dan Hospitalitas [Desire to move forward: Ranuklindungan Village strategy in realizing a tourism village]. Kepariwisataan dan Hospitalitas, 2(2), 63-76.

Murphy, P.E., \& Murphy, A.E. (2004). Strategic management for tourism communities: Bridging the gaps, Aspects of Tourism series (Clevedon (ed.)). Channel View Publications, United Kingdom. https://doi.org/10.21832/9781873150856

Murphy, P.E. (1985). Tourism: A community approach. Metheun, United Kingdom.

Ndlovu, J., Nyakunu, E., \& Auala, S. (2011). Community based tourism in Twyfelfontein conservancy: exploring local community's 
involvement. International Journal of Hospitality \& Tourism Systems, 4(2), 38-46.

Novelli, M., \& Gebhardt, K. (2007). Community based tourism in Namibia: reality show or window dressing?, Current Issues in Tourism, 10(5), 443-479. https://doi.org/10.2167/cit332.0

Nunkoo, R., Ramkissoon, H., \& Gursoy, D. (2012). Public trust in tourism institutions. Annals of Tourism Research, 39(3), $1538-1564$. https://doi.org/10.1016/j.annals.2012.04.004

Oka, I M.D., Darmayanti, P.W., \& Sonder, I W. (2021). Turtle conservation in Serangan Island: the implementation of community-based tourism concepts in tourism development. PalArch's Journal of Archaeology of Egypt / Egyptology, 18(2), 172-182. https://archives.palarch.nl/index.php/jae/article/view/5668

Oka, I M.D., \& Darmayanti, P.W. (2020). Environmental factors: dominant motivation of the Bongan community to support the development of tourist village. Journal of Business on Hospitality and Tourism, 6(1), 104-112. https://doi.org/10.22334/jbhost.v6i1.195

Oka, I M.D., Winia, I N., \& Pugra, I W. (2017). Pemberdayaan Masyarakat Melalui Pelatihan Pengolahan Masakan Seafoods Untuk Menunjang Pariwisata Di Desa Wisata Serangan [Community empowerment through training in processing seafood dishes to support tourism in Serangan Tourism Village]. Bhakti Persada: Jurnal Aplikasi IPTEKS, $1(1), 62$. http://ojs.pnb.ac.id/index.php/BP/article/view/250

Oka, I M.D., Winia, I N., \& Sadia, I K. (2019). The Implication of the Development of Serangan Tourist Village from the Economic Perspective. 383(ICSS 2019), 168-172. https://doi.org/10.2991/icss-19.2019.10

Okazaki, E. (2008). A Community based tourism model: its conception and use. Journal of Sustainable Tourism, 21(10), 511-529. https://doi.org/10.1080/09669580802159594

Priatmoko, S., Kabil, M., Purwoko, Y., \& David, L.D. (2021). Rethinking sustainable community-based tourism: a villager's point of view and case study in Pampang Village, Indonesia. Sustainability, 13, 3245. https://doi.org/10.3390/su13063245

Putra, I N.D., \& Pitana, I G. (2010). Pariwisata Pro-Rakyat Meretas Jalan Mengentaskan Kemiskinan di Indonesia [Pro-People Tourism Paves the Way for Alleviating Poverty in Indonesia]. Kementerian Kebudayaan dan Pariwisata, Indonesia.

Putra, T. (2019). A Review on penta helix actors in village tourism development and management. Journal Businsess Hospitality and Tourism, 5(1), 63-75.

Reid, D.G., Mair, H., \& George, W. (2004). Community tourism planning a self-assessment instrument. Annals of Tourism Research, 31(3), 623-639. https://doi.org/10.1016/j.annals.2004.01.007

Richards, G., \& Hall, D. (2000). Tourism and sustainable community development. Routledge, United Kingdom

Saarinen, J. (2006). Traditions of sustainability in tourism studies. Annals of Tourism Research, 33(4), 1121-1140. https://doi.org/10.1016/j.annals.2006.06.007

Saayman, M., \& Giampiccoli, A. (2016). Community-based and pro-poor tourism: Initial assessment of their relation to community development. European Journal of Tourism Research, 12, 145-190.

Sadia, I K., \& Oka, I M.D. (2012). Motivasi tenaga kerja bali bekerja di mediterranean shipping company (MSC) [Motivation of balinese workers to work at mediterranean shipping company (MSC)]. Jurnal Sosial Humaniora, 2(3), 221-236.

Scott, J. (2012). Tourism, civil society, and piece in Cyprus. Annals of Tourism Research, 39(4), $2114-2132$. https://doi.org/10.1016/j.annals.2012.07.007

Setiawina, N.D., Utama, M.S., \& Pringgana, G. (2020). The effect of community-based tourism on the performance of the tourism industry and community welfare in Nusa Penida District. Journal of Critical Reviews, 7(14), 1322-1333.

Simamora, H. (2001). Manajemen Sumber Daya Manusia [Human Resource Management]. STIE YKPN, Indonesia

Simpson, M.C. (2008). Community benefit tourism initiatives- a conceptual oxymoron?, Tourism Management, 29(1), 1-18. https://doi.org/10.1016/j.tourman.2007.06.005

Solimun. (2002). Multivariate Analisis, Structural Equation Modeling (SEM) Lisrel dan Amos. Brawijaya FMIPA, Indonesia

Suansri, P., \& Yeejaw-haw, S. (2013). CBT Standard Handbook. The Thailand CBT Institute, Thailand

Suasapha, A.H., \& Paturusi, S.A. (2015). CBT in management at Kedonganan Beach. In Pariwisata Berbasis Masyarakat Model Bali. Magister of Tourism. Udayana University, Indonesia.

Sugiyono. (2014). Metode Penelitian Manajemen [Management Research Methods]. Alfabeta, Indonesia

Sutrisna, E. (2011). Problematika perempuan bekerja di sektor pariwisata (studi kasus perhotelan) [The problem of women working in the tourism sector (hospitality case study)]. Jurnal Aplikasi Bisnis, 1(2), 97-102.

Timothy, A.B. (2015). Confirmatory factor analysis for applied research. The Guilfold Press.

Trejos, B., \& Chiang, L.N. (2009). Local economic linkages to CBT in Rural Costa Rica, Singapore. Journal of Tropical Geography, 30, 373-387. https://doi.org/10.1111/j.1467-9493.2009.00375.x

Utama, I G.B.R., \& Trimurti, C. (2019). The correlation of attraction with revisit intention of agritourism Pelaga Badung Bali, Indonesia. SINTESA Prosiding, 315-321. https://doi.org/10.9744/ijbs.2.2.119-124

Utomo, S.J., \& Satriawan, B. (2017). Strategi pengembangan desa wisata di Kecamatan Karangploso Kabupaten Malang [Tourism village development strategy in Karangploso District, Malang Regency]. Neobis, 11(2), 142-153. https://doi.org/10.21107/nbs.v11i2.3381

Winia, I N., Oka, I M.D., \& Pugra, I W. (2019). The Implementation of the community-based tourism at Tista Tourist Village. In International Conference on Applied Science and Technology 2019-Social Sciences Track (ICASTSS 2019). https://doi.org/10.2991/icastss-19.2019.15

Article history: Received: 17.05.2021 Revised: 06.08.2021 Accepted: 10.09.2021 Available online: 01.10.2021 